\title{
Ecological and Genetic Implications of Pigmentation in Staphylococcus aureus
}

\author{
By J. GRINSTED AND R. W. LACEY \\ Department of Bacteriology, University of Bristol, Bristol, BS8 ITD
}

(Received 3I July 1972)

\begin{abstract}
SUMMAR Y
On storage, pigmented (orange or yellow) strains of Staphylococcus aureus produce non-pigmented variants which are more susceptible to desiccation and to linoleic acid than are the corresponding wild strains. The association of these properties could explain why most staphylococci isolated from clinical sources are pigmented, although the pigmented character is lost at high frequency in vitro.

The genes determining these properties are not borne by a typical plasmid since the capacity to produce pigment was not transducible, and no covalently closed circular DNA was detected in lysates of three pigmented strains. There was an apparent reduction in cellular DNA of 30 to $40 \%$ associated with the loss of these genes; however, DNA/DNA hybridization could not distinguish between total cellular DNA from a pigmented strain (FAR5) and that isolated from the corresponding non-pigmented variant.
\end{abstract}

\section{INTRODUCTION}

Non-pigmented derivatives of Staphylococcus aureus are often found in subcultures of stored organisms (Pinner \& Voldrich, 1932; Doudoroff, 1936); non-pigmented clones can arise in pigmented colonies, giving a sectored appearance (Servin-Massieu, 196I); and treatment with nitrosoguanidine can result in irreversible loss of the capacity to synthesize pigment (Altenbern, 1967). These observations suggest that the genes responsible for pigment production in $S$. aureus are located on a plasmid, but there is no proof for this (Novick \& Bouanchaud, I97I).

Although loss of the ability to synthesize pigment in Staphylococcus aureus appears to be irreversible, more than $90 \%$ of strains isolated from clinical sources are pigmented (Willis, Smith \& O'Connor, 1966). This strongly suggests that pigmented strains have some advantage over non-pigmented strains in vivo. In this paper we show that pigmented strains of $S$. aureus are more resistant than non-pigmented strains in vitro to such factors as desiccation and linoleic acid, which probably contribute to the elimination of staphylococci in vivo. The problem of the location of the genes coding for pigment production and for this increased resistance was also investigated.

\section{METHODS}

Strains. Strains of Staphylococcus aureus were obtained from clinical sources. Singlecolony isolates were stored on nutrient agar slopes at room temperature without subculture.

Media, bacteriophage typing, determination of antibiotic sensitivity, detection of haemolysin and lipase production and transduction. These were as described previously (Lacey, 1972).

Pigmentation. Observations of colonies on milk agar (Lacey, Alder \& Gillespie, 1970) were made after $48 \mathrm{~h}$ at $37^{\circ} \mathrm{C}$ followed by $48 \mathrm{~h}$ at $20^{\circ} \mathrm{C}$. 
Treatment with nitrosoguanidine. The method of Altenbern (1967) was used: cultures were treated with nitrosoguanidine ( $100 \mu \mathrm{g} / \mathrm{ml}$ for 10 to $60 \mathrm{~min}$ ) to give about $\mathrm{I} \%$ survival.

Survival of strains on glass. The method used was similar to that used for survival on skin (Lacey et al. 1970). Overnight broth cultures of the pigmented and the corresponding nonpigmented strains were mixed, washed in distilled water and resuspended in distilled water to give about $5 \times 10^{6} \mathrm{cocci} / \mathrm{ml}$. Grease-free glass rectangles $(40 \times 24 \mathrm{~mm})$ were inoculated with this suspension $(0.0 \mathrm{Iml} / \mathrm{rectangle})$, allowed to dry at room temperature (about $5 \mathrm{~min}$ ), and then placed at 37,30 or $20^{\circ} \mathrm{C}$. (The relative humidity at 30 and $37^{\circ} \mathrm{C}$ varied from 40 to $60 \%$, and at room temperature from 60 to $80 \%$.) After $5 \mathrm{~h}$ (or $20 \mathrm{~h}$ in the case of incubation at room temperature) the glass rectangles were sampled by placing their inoculated surfaces successively on 12 areas of milk agar. After incubation, the numbers of pigmented and non-pigmented colonies were recorded. Knowing the initial ratio of pigmented to non-pigmented cocci (obtained by plating the initial inoculum directly on milk agar), the survival of each non-pigmented variant relative to that of the corresponding pigmented strain could be calculated.

Determination of amount of DNA per cell. Cultures were grown aerobically overnight in nutrient broth at $37^{\circ} \mathrm{C}$ in an orbital incubator. Inocula of about $10^{6}$ bacteria $/ \mathrm{ml}$ were used and under these conditions stationary phase is usually reached within about $6 \mathrm{~h}$. Viable counts were made by mixing equal volumes of cultures of the pigmented and corresponding non-pigmented strain, and then plating suitable dilutions on nutrient agar, on nutrient agar $+\mathrm{I} \%(\mathrm{v} / \mathrm{v})$ glycerol monoacetate, and on milk agar. (Pigmented and nonpigmented strains were mixed to ensure that an accurate ratio was obtained, regardless of the efficiency of dilution and plating. The mixtures were plated on three media to guard against the possibility that one of the strains was selectively inhibited by one of them.) The overnight cultures were harvested separately by centrifugation at $37000 \mathrm{~g}$ at $0^{\circ} \mathrm{C}$, washed with saline and resuspended in $5 \%(\mathrm{w} / \mathrm{v})$ trichloroacetic acid (TCA). After $30 \mathrm{~min}$ at $0{ }^{\circ} \mathrm{C}$ the mixtures were centrifuged and the pellets resuspended in $5 \%$ TCA $(2 \mathrm{ml}$ of TCA for every $10 \mathrm{ml}$ of original culture volume) and heated at $90^{\circ} \mathrm{C}$ for $20 \mathrm{~min}$. The supernatant fiuid was then assayed by the diphenylamine method of Burton, as modified by Giles \& Myers (1965). Calf thymus DNA (Sigma London Chemical Co. Ltd, London, S.W.6) was used as the standard.

Ethidium bromide/CsCl-gradient centrifugation. Cultures were labelled with tritiated thymidine, lysed with lysostaphin, and the lystates centrifuged in ethidium bromide/CsClgradients as described previously (Lacey \& Grinsted, 1972).

Preparation of DNA. Non-radioactive DNA was prepared from overnight cultures grown in nutrient broth at $37^{\circ} \mathrm{C}$. Cultures were harvested, washed with SET buffer (0.15 M-NaCl, $0 . \mathrm{I} \mathrm{M}-\mathrm{Na}_{2}$ EDTA, 0.05 M-tris(hydroxymethyl)aminomethane, $\mathrm{pH} 8$ ) and resuspended in SET buffer. Lysostaphin $(50 \mu \mathrm{g} / \mathrm{ml})$ was added and the mixture then incubated at $37{ }^{\circ} \mathrm{C}$ for $30 \mathrm{~min}$. DNA was prepared from the resulting lysates by a method essentially the same as that of Marmur (196I).

Radioactive DNA was prepared from cultures after growth in $\left[5^{-3} \mathrm{H}\right]$ thymidine $(20 \mu \mathrm{Ci}$ / $\mathrm{ml}, 5 \mathrm{Ci} / \mathrm{mmol}$ ) or $\left[2^{-14} \mathrm{C}\right]$ thymidine ( $\mu \mathrm{Ci} / \mathrm{ml}, 6 \mathrm{I} \mu \mathrm{Ci} / \mu \mathrm{mol}$ ). Overnight cultures were diluted I: IOO with fresh nutrient broth, radioactive thymidine was added and incubation then continued in an orbital incubator at $37^{\circ} \mathrm{C}$. After 4 to $5 \mathrm{~h}$, the cultures were harvested and lysed as described above. Lysates were deproteinized with chloroform and then adjusted to a density of $\mathrm{I} \cdot 70 \mathrm{~g} / \mathrm{cm}^{3}$ by the addition of solid $\mathrm{CsCl}$ and $\mathrm{SSC}$ buffer $\left(0 \cdot \mathrm{I}_{5} \mathrm{M}-\mathrm{NaCl}\right.$, $0.015 \mathrm{M}$-trisodium citrate, $\mathrm{pH} 7)$. These solutions $(7.0 \mathrm{ml})$ were centrifuged in the $10 \times 10 \mathrm{ml}$ angle-head rotor of the MSE Superspeed 50 ultracentrifuge at $43000 \mathrm{rev}$. $/ \mathrm{min}$ at $20^{\circ} \mathrm{C}$ for 
$45 \mathrm{~h}$, and then fractionated into twenty 20 -drop fractions. Radioactivity in samples (0.0I $\mathrm{ml})$ of each fraction was determined and fractions containing the radioactive DNA were pooled and dialysed versus $2 \times \mathrm{SSC}$. These solutions of DNA were finally treated with ribonuclease A $\left(50 \mu \mathrm{g} / \mathrm{ml}\right.$ at $37^{\circ} \mathrm{C}$ for $\left.\mathrm{I} \mathrm{h}\right)$ and then pronase ( $100 \mu \mathrm{g} / \mathrm{ml}$ at $37^{\circ} \mathrm{C}$ for $\left.\mathrm{I} \mathrm{h}\right)$. All solutions of DNA were dialysed extensively versus $2 \times$ SSC.

DNA/DNA hybridization. The method was essentially that of Denhardt (1966), as described in detail by Saunders \& Grinsted (I972). Nitrocellulose filters containing unlabelled DNA ( $20 \mu \mathrm{g} /$ filter) from the pigmented or non-pigmented strain were added to solutions containing radioactive DNA from both the pigmented and the non-pigmented strain (one labelled with ${ }^{3} \mathrm{H}$ (about 50000 c.p.m.), the other with ${ }^{14} \mathrm{C}$ (about 5000 c.p.m.); o.0 I to $0.05 \mu \mathrm{g}$ of each). After incubation at $65{ }^{\circ} \mathrm{C}$ for 15 to $17 \mathrm{~h}$, the amounts of ${ }^{3} \mathrm{H}$ and ${ }^{14} \mathrm{C}$ which had bound to the filters were determined and corrected for the radioactivity which had bound to blank filters in the same solutions. (Less than $0 . \mathrm{I} \%$ of the input radioactivity bound to blank filters or to filters which contained $20 \mu \mathrm{g} / \mathrm{ml}$ of pseudomonad DNA.)

Since the unlabelled DNA on the filter is in excess, the proportion of labelled homologous DNA (which is isolated from the same strain as was the unlabelled DNA on the filter) which hybridizes to it is a direct measure of the efficiency of hybridization. The radioactivity from the other labelled DNA which hybridized was corrected for this efficiency and the corrected values used to calculate the proportion of labelled test DNA which could hybridize. Thus,

where

$$
\% \text { hybridized }=\frac{\text { c.p.m. test DNA hybridized }}{\text { input c.p.m. test DNA }} \times \frac{100}{\text { efficiency }},
$$

$$
\text { efficiency }=\frac{\text { c.p.m. homologous DNA hybridized }}{\text { input c.p.m. homologous DNA }} .
$$

Efficiencies of hybridization ranged from 0.3 to 0.5 .

Radioactivity was determined as described by Grinsted et al. (1972).

\section{RESULTS}

\section{Origin and general properties of strains}

Six hundred and thirty-one coagulase-positive strains of Staphylococcus aureus were isolated from hospital and non-hospital sources in Bristol during I967 and I968: 45 (7\%) gave white colonies, $217(34 \%)$ yellow, and $369(59 \%)$ orange. Single-colony isolates of four of the strains producing yellow pigment and three of those producing orange pigment were stored on agar slopes at room temperature. After I to 3 years, a proportion of the colonies ( 0.6 to $40 \%$ ) obtained by subculture of every one of these slopes was non-pigmented; one non-pigmented variant of each strain was investigated. (Although pigmented strains all gave rise to non-pigmented variants on storage, storage of non-pigmented strains never resulted in the appearance of a pigmented variant.) Another strain producing orange pigment (strain FAR5) was isolated in $197 \mathrm{I}$; after 3 months of storage non-pigmented variants comprised $0.02 \%$ of the colonies obtained after subculture of a slope of this strain. One of these variants was also studied.

Non-pigmented variants were identical to the corresponding pigmented strains in bacteriophage typing pattern and in many other properties (Table $\mathrm{I}$ ). (Exceptions were production of free coagulase by strains 6936 and 805 , and production of $\alpha$-toxin by strain 609 .) Compared with the corresponding pigmented strains, the variants often gave bigger colonies on 


\section{Table I. Properties of pigmented strains and} corresponding non-pigmented variants

\begin{tabular}{|c|c|c|c|c|c|c|c|c|c|c|}
\hline \multirow[b]{2}{*}{ Strain } & \multirow[b]{2}{*}{$\begin{array}{l}\text { Phage pattern } \\
\text { (R.T.D.) }\end{array}$} & \multirow[b]{2}{*}{$\begin{array}{l}\text { Antibiotic } \\
\text { resistance }\end{array}$} & \multirow{2}{*}{$\begin{array}{l}\text { Colour on } \\
\text { milk agar }\end{array}$} & \multirow{2}{*}{$\begin{array}{c}\text { Tween } \\
80 \\
\text { reac- } \\
\text { tion }\end{array}$} & \multirow{2}{*}{$\begin{array}{l}\text { Egg- } \\
\text { yolk } \\
\text { reac- } \\
\text { tion }\end{array}$} & \multicolumn{3}{|c|}{ Haemolysin } & \multirow[b]{2}{*}{$\begin{array}{l}\text { Coa- } \\
\text { gulase }\end{array}$} & \multirow[b]{2}{*}{$\begin{array}{l}\text { Cata- } \\
\text { lase }\end{array}$} \\
\hline & & & & & & $\alpha$ & $\beta$ & $\delta$ & & \\
\hline $\begin{array}{l}609 \\
609(V)\end{array}$ & $\begin{array}{l}6 / 47 / 53 / 54 / 75 / 85 \\
6 / 47 / 53 / 54 / 75 / 85\end{array}$ & $\begin{array}{l}\text { PN } \\
\text { PN }\end{array}$ & $\begin{array}{l}\text { Orange } \\
\text { White }\end{array}$ & $\begin{array}{l}- \\
-\end{array}$ & $\begin{array}{l}- \\
-\end{array}$ & $\begin{array}{l}+ \\
-\end{array}$ & - & $\begin{array}{l}+ \\
+\end{array}$ & $\begin{array}{l}+ \\
+\end{array}$ & $\begin{array}{l}+ \\
+\end{array}$ \\
\hline $\begin{array}{l}6936 \\
6936(V)\end{array}$ & $\begin{array}{l}81 / 47 / 53 / 54 / 75 / 77 / 84 \\
81 / 47 / 53 / 54 / 75 / 77 / 84\end{array}$ & - & $\begin{array}{l}\text { Yellow } \\
\text { White }\end{array}$ & $\begin{array}{l}- \\
-\end{array}$ & $\overline{-}$ & $\begin{array}{l}+ \\
+\end{array}$ & $\begin{array}{l}+ \\
+\end{array}$ & $\begin{array}{l}+ \\
+\end{array}$ & $\begin{array}{l}+ \\
-\end{array}$ & $\begin{array}{l}+ \\
+\end{array}$ \\
\hline $\begin{array}{l}\text { FAR5 } \\
\text { FAR5 (V) }\end{array}$ & $\begin{array}{l}79 / 47 / 53 / 54 / 84 / 85 \\
79 / 47 / 53 / 54 / 84 / 85\end{array}$ & $\begin{array}{l}\mathrm{PF} \\
\mathrm{PF}\end{array}$ & $\begin{array}{l}\text { Orange } \\
\text { White }\end{array}$ & $\begin{array}{l}- \\
-\end{array}$ & $\begin{array}{l}- \\
-\end{array}$ & $\begin{array}{l}+ \\
+\end{array}$ & - & $\begin{array}{l}+ \\
+\end{array}$ & $\begin{array}{l}+ \\
+\end{array}$ & $\begin{array}{l}+ \\
+\end{array}$ \\
\hline $\begin{array}{l}186 \\
186(V)\end{array}$ & $\begin{array}{l}77 / 83 \mathrm{~A} / 84 / 85 \\
77 / 83 \mathrm{~A} / 84 / 85\end{array}$ & $\begin{array}{l}\text { PST } \\
\text { PST }\end{array}$ & $\begin{array}{l}\text { Yellow } \\
\text { White }\end{array}$ & $\overline{-}$ & $\begin{array}{l}- \\
-\end{array}$ & $\begin{array}{l}+ \\
+\end{array}$ & $\overline{-}$ & $\begin{array}{l}+ \\
+\end{array}$ & $\begin{array}{l}+ \\
+\end{array}$ & $\begin{array}{l}+ \\
+\end{array}$ \\
\hline $\begin{array}{l}16 \\
16(V)\end{array}$ & $\begin{array}{l}\text { 3A } \\
3 \mathrm{~A}\end{array}$ & $\begin{array}{l}\mathbf{P} \\
\mathbf{P}\end{array}$ & $\begin{array}{l}\text { Yellow } \\
\text { White }\end{array}$ & $\overline{-}$ & $\begin{array}{l}- \\
-\end{array}$ & $\begin{array}{l}+ \\
+\end{array}$ & $\begin{array}{l}- \\
-\end{array}$ & $\begin{array}{l}+ \\
+\end{array}$ & $\begin{array}{l}+ \\
+\end{array}$ & $\begin{array}{l}+ \\
+\end{array}$ \\
\hline $\begin{array}{l}76 \mathrm{I} \\
76 \mathrm{I}(\mathrm{V})\end{array}$ & $\begin{array}{l}85 \\
85\end{array}$ & $\begin{array}{l}\text { PSTEN } \\
\text { PSTEN }\end{array}$ & $\begin{array}{l}\text { Yellow } \\
\text { White }\end{array}$ & $\begin{array}{l}- \\
-\end{array}$ & $\begin{array}{l}- \\
-\end{array}$ & $\begin{array}{l}+ \\
+\end{array}$ & $\begin{array}{l}+ \\
+\end{array}$ & $\begin{array}{l}+ \\
+\end{array}$ & $\begin{array}{l}+ \\
+\end{array}$ & $\begin{array}{l}+ \\
+\end{array}$ \\
\hline $\begin{array}{l}805 \\
805(V)\end{array}$ & $\begin{array}{l}84 / 85 \\
84 / 85\end{array}$ & $\begin{array}{l}\text { PSTE } \\
\text { PSTE }\end{array}$ & $\begin{array}{l}\text { Orange } \\
\text { White }\end{array}$ & $\begin{array}{l}+ \\
+\end{array}$ & $\begin{array}{l}+ \\
+\end{array}$ & $\begin{array}{l}+ \\
+\end{array}$ & $\begin{array}{l}- \\
-\end{array}$ & $\begin{array}{l}+ \\
+\end{array}$ & + & $\begin{array}{l}+ \\
+\end{array}$ \\
\hline $\begin{array}{l}88 \\
88(V)\end{array}$ & $\begin{array}{l}\text { N.T. } \\
\text { N.T. }\end{array}$ & $\begin{array}{l}\text { PST } \\
\text { PST }\end{array}$ & $\begin{array}{l}\text { Orange } \\
\text { White }\end{array}$ & $\begin{array}{l}+ \\
+\end{array}$ & $\begin{array}{l}+ \\
+\end{array}$ & $\begin{array}{l}+ \\
+\end{array}$ & $\begin{array}{l}- \\
-\end{array}$ & $\begin{array}{l}+ \\
+\end{array}$ & - & $\begin{array}{l}+ \\
+\end{array}$ \\
\hline
\end{tabular}

(V), non-pigmented; R.T.D., routine test dilution; N.T., non-typable.

$P$, produces penicillinase. Resistance to: $N$, neomycin; $F$, fusidic acid; $S$, streptomycin; $T$, tetracycline; E, erythromycin.

\section{Table 2. Growth in mixed culture}

Overnight broth cultures of pigmented strains and their non-pigmented variants were mixed, diluted to about $10^{5}$ bacteria/ml and then incubated statically at $37^{\circ} \mathrm{C}$ for $5 \mathrm{~h}$. The ratio of non-pigmented cells to pigmented was determined before and after incubation by plating on milk agar.

$\begin{array}{lc}\text { Strains } & \begin{array}{c}\text { Increase of } \\ \text { non-pigmented } \\ \text { variant* } \\ (\%)\end{array} \\ 609 / 609(\mathrm{~V}) & \mathrm{I} / \mathrm{0}, \mathrm{I} 38 \\ 6936 / 6936(\mathrm{~V}) & 104, \mathrm{I} 20 \\ \text { FAR5/FAR5 }(\mathrm{V}) & 88, \mathrm{I} 29 \\ 186 / 186(\mathrm{~V}) & 135, \mathrm{I} 48 \\ \text { 16/16(V) } & 162,197 \\ 761 / 761(\mathrm{~V}) & 156,122 \\ 805 / 805(V) & 364,284 \\ 88 / 88(\mathrm{~V}) & 104,108\end{array}$

* These values are the ratios of non-pigmented to pigmented bacteria after incubation as a percentage of the ratio before incubation obtained in duplicate experiments.

solid media and had faster growth rates in liquid media. These differences were not consistent, and broth cultures of either usually grew to about the same culture density overnight. However, if cultures of pigmented and non-pigmented strains were mixed and the mixture incubated at $37^{\circ} \mathrm{C}$, some of the non-pigmented variants could outgrow the corresponding pigmented strains (Table 2). 
Table 3. Effects of nitrosoguanidine on pigment production by strains 609 and 6936

Strains were treated with nitrosoguanidine and then plated on milk agar as described in Methods.

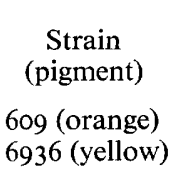

Strains
then plated

Total
893
1010

Numbers of colonies

$\begin{array}{cccc}\begin{array}{c}\text { Altered } \\ \text { in colour }\end{array} & \text { Orange } & \text { White } & \text { Yellow } \\ 322 & 860 & 18 & 15 \\ 86 & 0 & 27 & 983\end{array}$

\section{Effects of treatment with nitrosoguanidine}

After treatment with nitrosoguanidine, both yellow-pigmented and non-pigmented mutants were obtained from strain 609 (which produces orange pigment); treatment of strain 6936 (yellow-pigmented) resulted in non-pigmented mutants but no orange-pigmented mutants (Table 3). If yellow-pigmented mutants from strain 609 were further treated with nitrosoguanidine, non-pigmented derivatives occurred (about $3 \%$ of the survivors), but there was no reversion to orange.

These results are consistent with the existence of at least two genes coding for pigment in the orange-pigmented strains, one coding for orange pigment and one for yellow, and of at least one gene, coding for yellow pigment, in the yellow-pigmented strains. The high incidence of non-pigmented derivatives after mutagenesis of the orange-pigmented strain (609) may indicate that the genes coding for both orange and yellow pigment are located on the same linkage group. (In all experiments involving treatment with nitrosoguanidine, about 20 to $30 \%$ of the pigmented survivors showed an altered intensity of pigment. Altenbern (1967) has made a similar observation.)

The non-pigmented variants of strains 609 and 6936 were treated with nitrosoguanidine. No pigmented derivatives were found in $10^{5}$ survivors of each strain. Hence, although the capacity to synthesize pigment is lost rather easily, it cannot be regained at a similar frequency: loss of pigment is essentially irreversible, as reported by Altenbern (1967).

\section{Survival on glass}

Cultures were spread and dried on glass and then incubated at various temperatures. Compared with the corresponding pigmented strains, only I to $35 \%$ of bacteria from nonpigmented strains survived this treatment (Table 4). Furthermore, the effect was more marked at $37^{\circ} \mathrm{C}$ than at $20^{\circ} \mathrm{C}$ (Table 4). If, immediately after the inocula had dried, the glass was incubated at $100 \%$ humidity, there was little subsequent change in the relative numbers of pigmented and non-pigmented cells. This indicates that the non-pigmented cells were probably killed by desiccation rather than by some other factor.

Mutants of strains 609 and 6936 which had an altered intensity of pigment were also tested for survival on glass relative to the wild-types: no differences were detected. It appears probable therefore that the genes determining production of pigment and those determining enhanced survival to desiccation are distinct and probably linked.

\section{Sensitivity to linoleic acid}

Non-pigmented strains were more sensitive to linoleic acid than the corresponding pigmented strains (Table 5). This difference is another factor which could affect the composition 


\section{Table 4. Survival of non-pigmented variants of \\ Staphylococcus aureus on glass}

Cultures of pigmented strains of Staphylococcus aureus and the non-pigmented variants were mixed, spread on glass, dried, and then incubated for $5 \mathrm{~h}$ at 37 or $30^{\circ} \mathrm{C}$, or for $20 \mathrm{~h} \mathrm{at} 20^{\circ} \mathrm{C}$. Percentage survival of the non-pigmented strains compared with the corresponding pigmented strains was calculated as described in Methods.

\begin{tabular}{lccc}
\multicolumn{3}{c}{ Survival $(\%)$} \\
Strain & $37{ }^{\circ} \mathrm{C}$ & $30^{\circ} \mathrm{C}$ & $20{ }^{\circ} \mathrm{C}$ \\
$609(\mathrm{~V})$ & 5 & II & 20 \\
$6936(\mathrm{~V})$ & 3 & 4 & 7 \\
FAR5 (V) & $<\mathrm{I}$ & 4 & 7 \\
I86(V) & 2 & 9 & 7 \\
I6 (V) & 20 & 31 & 35 \\
76 I (V) & 2 & 4 & 19 \\
$805(V)$ & 3 & 6 & 24 \\
$88(V)$ & 12 & 15 & 23
\end{tabular}

Table 5. Effect of sodium linoleate on growth of strains of Staphylococcus aureus

Strains were plated on nutrient agar which contained doubling dilutions of sodium linoleate and incubated at $37^{\circ} \mathrm{C}$.

\begin{tabular}{|c|c|c|c|}
\hline Strain & $\begin{array}{c}\text { Minimum } \\
\text { inhibitory } \\
\text { concentration } \\
\text { of sodium } \\
\text { linoleate } \\
(\%, w / v)^{*}\end{array}$ & & $\begin{array}{c}\text { Minimum } \\
\text { inhibitory } \\
\text { concentration } \\
\text { of sodium } \\
\text { linoleate } \\
(\%, w / v)^{*}\end{array}$ \\
\hline $\begin{array}{l}609 \\
609(V)\end{array}$ & $\begin{array}{l}0.10 \\
0.025\end{array}$ & $\begin{array}{l}76 \mathrm{r} \\
76 \mathrm{I}(\mathrm{V})\end{array}$ & $\begin{array}{l}0.05 \\
0.01\end{array}$ \\
\hline $\begin{array}{l}6936 \\
6936(V)\end{array}$ & $\begin{array}{l}0.10 \\
0.025\end{array}$ & $\begin{array}{l}805 \\
805(V)\end{array}$ & $\begin{array}{l}0.10 \\
0.025\end{array}$ \\
\hline $\begin{array}{l}\text { FAR5 } \\
\text { FAR } 5(\mathrm{~V})\end{array}$ & $\begin{array}{l}0.10 \\
0.05\end{array}$ & $\begin{array}{l}88 \\
88(V)\end{array}$ & $\begin{array}{l}0.10 \\
0.025\end{array}$ \\
\hline $\begin{array}{l}16 \\
16(V)\end{array}$ & $\begin{array}{l}0.05 \\
0.01\end{array}$ & & \\
\hline
\end{tabular}

* The minimum inhibitory concentration is the lowest concentration which permitted growth of less than half the colonies which could grow in the absence of linoleate.

of the population of staphylococci in vivo, since unsaturated fatty acids are thought to be important in the elimination of these bacteria from the skin (Ricketts, Squire \& Topley, 195I).

\section{Transduction}

Plasmid-borne genes can be transferred at high frequency from strain 609 to strain 6936 (Lacey, 1971); attempts were made to transduce the ability to produce pigment from strain 609 to a mutant of strain 6936 which was novobiocin-resistant and non-pigmented. The donor (strain 609) was used both as whole cells in mixed culture testing, and as a mitomycin C-induced lysate. The mixtures were plated on milk agar containing novobiocin $(5 \mu \mathrm{g} / \mathrm{ml})$. In some cases these plates were supplemented with sodium linoleate $(0.05 \%, \mathrm{w} / \mathrm{v})$, in others the mixtures were spread on glass and incubated at $37^{\circ} \mathrm{C}$ for $\mathrm{I} \mathrm{h}$ before being plated. Both of these procedures should select for pigmented transductants of strain 6936 if production 
Table 6. Amount of DNA in various strains of Staphylococcus aureus

The amount of DNA/bacterium of stationary-phase cultures of various strains of Staphylococcus aureus was determined as described in Methods. The results are of duplicate experiments performed at different times.

\begin{tabular}{|c|c|c|}
\hline Strain & $\begin{array}{c}\text { DNA/viable } \\
\text { bacterium } \\
\left(\mathrm{g} \times 10^{-14}\right)\end{array}$ & $\begin{array}{c}\text { DNA in } \\
\text { non-pigmented } \\
\text { strain compared } \\
\text { with pigmented } \\
(\%)\end{array}$ \\
\hline $\begin{array}{l}609 \\
609(V)\end{array}$ & $\begin{array}{l}I \cdot 12,1 \cdot 20 \\
0.71,0.69\end{array}$ & 63,57 \\
\hline $\begin{array}{l}6936 \\
6936(V)\end{array}$ & $\begin{array}{ll}\mathrm{I} \cdot 28, & \mathrm{I} \cdot 45 \\
0 \cdot 82, & \mathrm{I} \cdot 02\end{array}$ & 64,7 I \\
\hline $\begin{array}{l}\text { FAR5 } \\
\text { FAR5 (V) }\end{array}$ & $\begin{array}{l}\mathrm{I} \cdot 35, \mathrm{I} \cdot 40 \\
0.85,0.90\end{array}$ & 63,64 \\
\hline
\end{tabular}

of pigment is linked to enhanced survival. Transfer of the capacity to synthesize pigment could not be detected in mixed culture or in formal transduction experiments. However, the selection methods used are rather insensitive and the occurrence of transduction of the genes at low frequency has not been excluded.

\section{Ethidium bromide/CsCl-gradient centrifugation}

Staphylococcal plasmids can be isolated as covalently closed circular DNA (CCC-DNA) on ethidium bromide/CsCl-gradients (Novick \& Bouanchaud, I97I). Lacey \& Grinsted (1972) showed that CCC-DNA could be detected in the pigmented strain FAR5 when it contained a penicillinase plasmid, but CCC-DNA could not be detected in derivatives of FAR 5 which had lost the penicillinase plasmid but still formed pigment. Ethidium bromide/ $\mathrm{CsCl}$-gradient centrifugation was carried out on radioactive lysates of antibiotic-sensitive derivatives of the pigmented strains 609 and 6936: in neither case could a radioactive satellite of CCC-DNA be detected. Thus, when lacking known plasmids, pigmented strains contain no detectable CCC-DNA.

\section{Comparison of DNA from pigmented and non-pigmented strains}

Stationary-phase cultures of strains 609,6936 and FAR5 all contained I to $\mathrm{I} \cdot 5 \times \mathrm{IO}^{-14} \mathrm{~g}$ DNA/viable bacterium, but in the non-pigmented variants there was only 60 to $70 \%$ of this amount (Table 6). These differences were not due to increased clumping of the pigmented strains. (Cultures of the pigmented strains and their corresponding non-pigmented variants were mixed and then counted, either with, or without treatment with triton X-1oo $(\mathrm{I} \%, \mathrm{w} / \mathrm{v})$. There were no significant differences in the proportions of pigmented to nonpigmented bacteria.) It is inferred that the genes coding for pigment production and for enhanced survival in pigmented strains are part of this extra DNA.

The relationship between the DNA of strain FAR5 and that of its non-pigmented derivative was investigated by a method of DNA/DNA hybridization in which the proportion of radioactive DNA which could hybridize with an excess of unlabelled DNA was determined. In the situation where all of the sequences of the radioactive DNA are represented in the unlabelled DNA, as is obviously the case when both radioactive DNA and unlabelled DNA were isolated from the same strain, $100 \%$ of the radioactive DNA should be able to hybridize. Values of $100 \%$ hybridization were obtained when labelled and unlabelled DNA from the same source were hybridized and radioactive DNA from non-pigmented cells could 


\section{Table 7. DNA/DNA hybridization of DNA from pigmented strains and the corresponding non-pigmented variants}

Hybridization was carried out with radioactive DNA in solution and excess unlabelled DNA bound to the filter as described in Methods.

\begin{tabular}{|c|c|c|}
\hline \multirow[b]{2}{*}{ Radioactive DNA } & \multicolumn{2}{|c|}{ Radioactive DNA hybridized $(\%)^{*}$} \\
\hline & $\begin{array}{c}\text { FAR5-DNA } \\
\text { on filter }\end{array}$ & $\begin{array}{c}\text { FAR5(V)-DNA } \\
\text { on filter }\end{array}$ \\
\hline From FAR5 & $99 \cdot 9(9 I-I I 6) \pm 6.5(I 4)$ & IOI·I $(93-108) \pm 3 \cdot 6(20)$ \\
\hline From FAR5 (V) & $100 \cdot 3(92-1 \mathrm{II}) \pm 5.0(27)$ & $99.9(93-104) \pm 3.9(8)$ \\
\hline
\end{tabular}

* This was calculated as described in Methods. The data shown are \% hybridized, range, standard deviation and number of determinations.

hybridize about $100 \%$ with unlabelled DNA from pigmented cells (Table 7), so the latter contains all the sequences contained in the former. If the additional DNA in the pigmented strain is comprised wholly of sequences which are different from those which make up the rest of the DNA, less than $100 \%$ of labelled DNA from the pigmented strain could hybridize with unlabelled DNA from the non-pigmented strain. But a value of about I00\% was obtained (Table 7). So DNA from strain FAR5 does not contain many sequences not found in DNA from the non-pigmented variant, in spite of the difference in the amount of DNA/cell.

\section{DISCUSSION}

The skin surface is an important carriage site for Staphylococcus aureus; elimination of the organism from the skin is probably a result of both desiccation and destruction by unsaturated fatty acids (Ricketts et al. 1951; Lacey, 1968; Lacey et al. 1970). All nonpigmented strains tested were more sensitive to desiccation and to linoleic acid than were the corresponding pigmented strains. These differences could put non-pigmented strains at a disadvantage in vivo, and provide a plausible explanation for the predominance of pigmented strains in clinical isolates.

Irreversible loss of characters at high frequency usually indicates that the relevant genes are part of a plasmid: pigmented strains lost the capacity to synthesize pigment and to resist desiccation and linoleic acid at high frequency when stored on nutrient agar slopes. But no plasmid could be detected physically (as CCC-DNA) in antibiotic-sensitive pigmented strains, and the capacity to synthesize pigment could not be transduced at high frequency, facts which argue against a plasmid site for the genes coding for these characters.

These apparently contradictory results can be reconciled if the genes determining pigment production and enhanced resistance to desiccation and linoleic acid are carried on a linkage group which is not essential for viability in vitro, but is too large to satisfy other criteria of plasmids. This possibility was suggested by finding that cells of non-pigmented variants apparently contained only 60 to $70 \%$ of the amount of DNA contained by the corresponding pigmented strains. If this extra DNA in pigmented strains comprises a single linkage group, it would have a molecular weight of 200 to 300 million daltons, almost certainly too large to be transduced in toto and to be isolated as CCC-DNA on ethidium bromide/ CsCl-gradients. But DNA/DNA hybridization showed that any extra DNA in pigmented strains comprises sequences which also occur in the non-pigmented variants, so the postulated large linkage group in pigmented strains would be comprised predominantly of sequences also found in the chromosome. 
This work was partly supported by grants from the Medical Research Council to Professor M. H. Richmond.

\section{REFERENCES}

ALtenbern, R. A. (1967). Genetic studies of pigmentation of Staphylococcus aureus. Canadian Journal of Microbiology 13, 389-395.

DENhARDT, D. T. (1966). A membrane-filter technique for the detection of complementary DNA. Biochemical and Biophysical Research Communications 23, 641-646.

Doudoroff, M. (1936). Association of characters among dissociates from Staphylococcus aureus. Proceedings of the Society for Experimental Biology and Medicine 34, 216-217.

GILES, K. W. \& MYERS, A. (I965). An improved diphenylamine method for the estimation of deoxyribontcleic acid. Nature, London 205, 93-93.

Grinsted, J., Saunders, J. R., Ingram, L., Sykes, R. B. \& Richmond, M. H. (1972). Properties of an R factor which originated in Pseudomonas aeruginosa 1822. Journal of Bacteriology I10, 529-537.

LACEY, R. W. (1968). Antibacterial action of human skin. In vivo effect of acetone, alcohol and soap on behaviour of Staphylococcus aureus. British Journal of Experimental Pathology 49, 209-21 5.

LACEY, R. W. (197I). Transfer of tetracycline-resistance between strains of Staphyloccocus aureus in mixed cultures. Journal of General Microbiology 69, 229-237.

LACEY, R. W. (1972). Genetic control in methicillin-resistant strains of Staphylococcus aureus. Journal of Medical Microbiology 5, 497-508.

Lacey, R. W., Alder, V. G. \& Gillespie, W. A. (1970). The survival of Staphylococcus aureus on human skin. An investigation using mixed cultures. British Journal of Experimental Pathology 5r, 305-313.

LACEY, R. W. \& GRINSTED, J. (1972). Linkage of fusidic acid-resistance to the penicillinase plasmid in Staphylococcus aureus. Journal of General Microbiology 73, 50I-508.

MARMUR, J. (196r). A procedure for the isolation of deoxyribonucleic acid from microorganisms. Journal of Molecular Biology 3, 208-218.

Novick, R. P. \& BouAnCHAUd, D. (1971). Extrachromosomal nature of drug resistance in Staphylococcus aureus. Annals of the New York Academy of Sciences 182, 279-294.

Pinner, M. \& Voldrich, M. (1932). Derivation of Staphylococcus albus, citreus and roseus from Staphylococcus areus. Journal of Infectious Diseases 50, 185-202.

RicketTS, C. R., SquiRE, J. R. \& TOPLEY, E. (195I). Human skin lipids with particular reference to the selfsterilizing power of the skin. Clinical Science Io, 89-I I 2.

SAunders, J. R. \& Grinsted, J. (1972). Properties of RP 4, an R factor which originated in Pseudomonas aeruginosa S 8. Journal of Bacteriology II2, 690-696.

Servin-Massieu, M. (1961). Spontaneous appearance of sectored colonies in Staphyloccus aureus. Journal of Bacteriology 82, 316-317.

Willis, A. T., Smith, J. A. \& O'ConNor, J. J. (I966). Properties of some epidemic strains of Staphylococcus aureus. Journal of Pathology and Bacteriology 92, 345-358. 